\title{
OT PEАAKTOPA
}

В настоящее время в мире правит бал невидимый глазу коронавирус, который распространился по земному шару, используя самые современные средства коммуникации, и начал определять мораль, политику и экономику в глобальном масштабе. Относительно четко налаженная и функционирующая система отношений, связей, мнений и оценок начала обнаруживать свои слабые места. Начали захлопываться границы, и оказалось, что каждая страна, в какой бы союз с другими она не входила, отвечает за свое население индивидуально. Глобализация стала острой проблемой в разных отношениях. С потерей доходов, особенно от постоянного роста сервисных бизнесов, поплыла вниз экономика, начались банкротства и рост безработицы. И мы, возможно, будем свидетелями изменения моральных отношений, как это обычно бывало в истории во время массовых заболеваний. Об этом писал еще в середине первого тысячелетия до н.э. Фукидид в своей истории Пелопоннесской войны: «Сломленные несчастьем, люди, не зная, что им делать, теряли уважение к божеским и человеческим законам». Начало распространяться беззаконие: «Ни страх перед богами, ни закон человеческий не могли больше удержать людей от преступлений, так как они видели, что все погибают одинаково, и поэтому безразлично, почитать ли богов или нет». Мораль в условиях самоизоляции трансформируется, вынуждая людей, с одной стороны, более пристально вглядываться друг в друга в условиях домашнего ареста, а с другой стороны, воспринимать всех остальных как угрозу. Меняются идеалы.

Что же касается образования, то здесь пандемия фактически поставила эксперимент по массовому переходу к онлайн-обучению. Если до сих пор применение дистанционных технологий в мире неуклонно росло, особенно в системе дополнительного образования, то нынешняя ситуация показала неоднозначность этого процесса. Возросла в разы нагрузка на преподавателей и студентов при существенно снижающейся отдаче. Декларации о том, что онлайн-образование может быть приравнено к обычному, стали выглядеть в этих условиях весьма странно. Особенно если учесть, насколько меняется в этих условиях система контроля и усиливается стандартизация. Кроме того, меняется отношение к цифровизации обучения. Обучение в новых условиях показало, что виртуальная реальность может полностью замещать обычную реальность с массой вытекающих отсюда последствий не только для системы образования, но и для формирования личности. Радикально меняется ситуация с развитием свободной личности. И это ставит серьезнейшую проблему для социальной философии. 